\title{
Authority and Compulsion in Legal-Historical Method ${ }^{1}$
}

\author{
Caleb Goltz \\ ${ }^{1}$ Department of Political Science, Hartwick College, Oneonta, New York, United States \\ Correspondence: Caleb Goltz, Department of Political Science, Hartwick College, 311 Golisano Hall, 1 \\ Hartwick Drive, Oneonta, NY 13820, United States. Tel: 1-607-431-4498. E-mail: goltzc@hartwick.edu
}

Received: June 17, 2015 Accepted: July 7, 2015 Online Published: August 24, 2015

doi:10.5539/jpl.v8n3p149 URL: http://dx.doi.org/10.5539/jpl.v8n3p149

\begin{abstract}
Case law is often used as evidence of a political action, similar to a pamphlet or speech. Yet, legal decisions are different from other sources in that when they function as precedent they have authority not only in the case at hand, but also in similar future cases. Recovering and using case law in the process of doing qualitative research is then inherently normative in the sense that researchers' actions may influence the outcome of future legal cases. This article argues that case law in the common law world is a unique type of source presenting normative entanglements and challenges not found in other historical documents, and that these normative issues have been overlooked because the concept of authority has received little attention in qualitative methodology. Consideration of the authority of our source material helps us to understand not only the context of the original source, but also to anticipate and appreciate the future uses to which others may put our work.
\end{abstract}

Keywords: methodology, legal history, textual interpretation, text and context

\section{Introduction}

Conventional training in qualitative methodology implores researchers to approach their subjects without bias, preconceived notions, or normative agendas. Such training asks the researcher to disclaim authority about the subject, and let the sources speak authoritatively on their own terms instead. Yet, this convention of attempting to put authority in the source rather than the researcher is especially problematic when working with common law legal decisions that have the capacity to function as legal precedent both now and in the future. The recovery and use of common law precedents that are often long forgotten has the potential to change our notions of what the law is and ought to be. Common law precedents upset our visions of both chronology and authority of source material as they act as a form of authority across large spans of time and may be powerfully marshaled by a variety of interpreters, including researchers. The conventional idea that researchers are able to disclaim authority when dealing with historical documents may be impossible in the case of legal texts. Instead, our only option may be to accept the form of authority we practice and make the best use of it we can.

The special normative power of common law precedents is beginning to be noticed. In a recent essay laying out a methodology of comparative legal history, David Ibbetson brought the question of authority to the fore. He divides law into two levels - legal doctrine and legal outcomes - and in argues that in understanding doctrinal sources, "The crucial distinction is [...] the degree of authority they possess" (Ibbetson, 2012, 135-136). Yet, there is no similar mention of the authority of outcomes. Instead, Ibbetson notes that sometimes there is a "feedback loop" in which legal outcomes influence legal doctrine so that "judicial decisions can be treated as themselves generating legal rules" (Ibid, 140).

In furtherance of Ibbetson's turn to authority, but in contrast to his limitation of that authority to doctrine, this article argues that the question of authority permeates all levels of common law legal history because the unique role of precedent makes judicial decisions into potential legal rules. Ibbetson's distinction between doctrine and outcomes may work in civil systems, but it artificially divides the common law in a way that covers over the authority of legal outcomes in the common law world. The recovery and assembly of these powerful outcomes into an account of legal practices with the potential to bind the present, I conclude, makes common law history a uniquely normative-proscriptive endeavor. In order to produce a method of dealing responsibly with common law sources, we must account for the unique and powerful role played by precedent in the common law world.

\footnotetext{
${ }^{1}$ The author wishes to thank Joan Tronto, Yves Winter, Elizabeth Beaumont, Nancy Luxon, and participants in the University of Minnesota Political Theory Colloquium for their helpful feedback and encouragement on earlier drafts of this article.
} 
There are two types of authority that I work to describe in this article so that we can understand the fraught relationship between them. The first is the authority of the researcher, which has been approached in a two very different ways. First, there are deep contextualists who argue that contextualizing source material allows the researcher to act as a conduit for meaning rather than an authority. This approach or outlook has its modern genesis in the work of Herbert Butterfield, and Butterfield directly influenced a group of scholars that we now know as the Cambridge School. This School - congealed today around the figures of Quentin Skinner, John Dunn, and JGA Pocock - follows Butterfield in looking to a form of deep contextualism as a lodestar that might always portray the past in an unfamiliar light to avoid the trap of Whig history. Second, since the 1960's a diverse set of scholars have criticized the deference historians came to give authors and their efforts to understand intentionality in historical texts. They argue instead that the reader of a text always rightly participates in its authorship. In looking to the legal context, I argue that both methodological schools lack the tools to explain the forms of authority present in legal texts because they fail to recognize that a historian's responsibility to legal texts is not only general fidelity to the facts in a past time, but a fiduciary duty to the legal processes of the present and future. Precisely because the past is uniquely binding for the future in common law contexts, the line between doing historical work on the law and doing contemporary legal work is not always clear.

The sources I use in this article are drawn not only from history and law, but also political science. These diverse perspectives all take the identification and practice of power and authority as central themes. While this may be a bit unconventional for a paper on qualitative methodology, the historian Wilfrid Prest recently reminded us that, "Historians may not be the best persons to explicate their own methodological or theoretical underpinnings" (Prest 2012, 209). I take this as an invitation to approach the role of authority and compulsion in legal history from other vantage-points.

\section{Historical Authority and Authorship}

\section{1 'Chaste' History: Butterfield and Oakeshott}

In 1931, Herbert Butterfield changed what it meant to do critical history by interrogating the authority of the historian (Prest 2012, 209). He argued that historians have a strong tendency to go to the past looking for similarities to the present, tying events together across time and linking them to the here-and-now until it looks as if the past not only caused the present, but that our forefathers intended nothing else than to produce the twentieth century in its then-present form (Butterfield, 1965 [1931], 12). By this light we tend to overemphasize the ways that the victors of the past prefaced the modern era and were similar to us, while simultaneously downplaying the heritage we received from the primitive vestiges of a bygone area that we would like to believe are now fully vanquished. Viewing the present as an intentional product of an earlier enlightened age oversimplifies historical causation, assuming that history proceeds by force of human will rather than emerging as a happenstance collection of prior discordant projects. The present, Butterfield argued, was not produced by the force of any one victor, but rather by a set of multiple and divergent intentions that are only collectively - but not uniquely - still with us (Ibid, 24-25; see ch. 3 generally). Instead of telling a story of the victorious and glorious present, Butterfield argued that the essential starting point for doing good history is to recognize that the past is precisely not the present because it was, and is, dissimilar. The task of the historian who begins from the premise of dissimilarity, Butterfield argues, is to enter into a foreign world and tell its story.

The only value such a history has for the present is that even dissimilar worlds still have some commonalities that might eventually be noticed. "In reality," Butterfield writes, "the historian postulates that the world is in some sense always the same world and that even the men most dissimilar are never absolutely unalike" (Ibid, 9). Here Butterfield hedges a bit on the separation between past and present. Elsewhere he goes further, saying that:

The historian is something more than the mere passive external spectator. Something more is necessary if only to enable him to seize the significant detail and discern the sympathies between events and find the facts that hang together. By imaginative sympathy he makes the past intelligible to the present. He translates its conditioning circumstances into terms which we today can understand. It is in this sense that history must always be written from the point of view of the present. It is in this sense that every age will have write its history over again (Ibid, 51).

Here Butterfield comes around to the primary problem of historiography in the twentieth century: Given that the historian is always and inevitably writing for the present, to what authority or authorities does the author owe fidelity?

Michael Oakeshott argues that our fidelity is owed to the past. In his essay The Activity of Being an Historian, Oakeshott argues that modern historians define themselves against the ancient mode of doing history. The 
ancients, he argues, looked to the past for practical, scientific, or contemplative reasons. Practical historians take a first person perspective on the past, always looking at how the past relates to them and might provide information on how they might inhabit the world better, or make the world more friendly to human habitation. Scientific historians look to the past as a set of data points that indicate general trends or laws which, once revealed, might prove useful in anticipating the future. Contemplative historians make use of the past as a storehouse of images that they can call on as a cultural currency in art, literature, or politics. All of these reasons are instramentalizations of the past that make it contemporary and put it to work in the service of the present.

Modern historians, Oakeshott argues, try to distinguish themselves from the ancients by distinguishing between "practice" and "history" $(1955,164)$. All of what the ancients did was practice because they used history or historical examples to do intellectual work for them. Further, viewing history with an eye to its usefulness implies a normative judgment about that history: it is good history insofar as it enables us to further ourselves in the world. The practical bent of the ancient historians is understandable because historical evidence is almost always purposive. From walls, to clay pots, to political treatises, the pieces of the past that historians encounter serve a purpose; we might describe them as goal-oriented. Evidence is written in an "idiom of practice" and it is tempting for the historian to respond to that evidence in a similarly practical register that engages in "the primordial activity of making ourselves at home in the world by assimilating our past to our present" (Ibid, 161; 165 , emphasis in original). The problem with this assimilation is that it necessarily imposes an unwarranted value judgment and moral structure upon the past. This move makes the past present, and this nearsightedness is a total lens that excludes other ways of seeing (Ibid, 163).

History proper is founded upon the rejection of the ancient method, and all of its practical considerations. It begins by acknowledging that, "the practical attitude to the past is the chief undefeated enemy of "history" (Ibid, 165) that frustrates the historian's attempt to make sure that "the past is not viewed in relation to the present, and is not treated as if it were present" (Ibid, 154, emphasis in original). The past is not judged. For the historian, "there are no successes and no failures and no illegitimate children ... [n] othing is approved ... and nothing is denounced" (Ibid). The modern historian, Oakeshott argues, should be an empty vessel.

\subsection{The Cambridge School}

Sometimes agreeing and sometimes disagreeing with Oakeshott, Quentin Skinner has exerted much energy on explicating what constitutes good intellectual history, and what does not. He argues that two prominent approaches are doomed to fail. First, focusing exclusively on the text as a key to its own meaning forces us to account for gaps in the text with our own expectations, causing the historian to accidentally impose a foreign paradigm on his subject of research, turning the product into something more mythological than historical (Skinner 1969, 6-7). And yet, while context is necessary to good interpretation, it is not adequate. Skinner argues that good intellectual history is done by focusing on the outcome the author of the text in question aimed to produce given his context (Ibid, 48-49). This focus on authorial intention in historically localized conditions limits the potential impact of intellectual history, so that "the classic texts cannot be concerned with our questions and answers, but only with their own" (Ibid, 50). Although Skinner has moderated his tone in the last forty years, his convictions remain largely unchanged. The essential element of doing the history of ideas, he wrote recently, is to "situate the texts we study within such intellectual contexts as enable us to make sense of what their authors were doing in writing them" (Skinner, 2002, 3). For Skinner, interpretation is comprised of situating a text within its context(s) in an effort to accurately discern the results the author was trying to produce and how his behavior would have been understood by the intended audience. ${ }^{2}$ Political texts, in contradistinction to literature, are not a collection of words; rather, they are an effort to communicate with other people to get them to do some act. Thus, the meaning of political texts - insofar as they are political ${ }^{3}-$ is always to understand the aims that text pursued.

This theory of communication forestalls two common interpretive possibilities. First, in spite of his use of the ideas of "intent" and "intention", Skinner does not take the author as the final, or even primary, arbiter of the text's meaning (Skinner, 2002, 3). Instead, the primary focus of study is how the audience would have received

\footnotetext{
${ }^{2}$ The reach of Skinner's method is limited by a theory of language and communication best understood in light of the twentieth century's complex and disjointed relationship with language. In 1936, A.J. Ayer pushed positivism into philosophy when he published Language, Truth, and Logic. He argued in part that many of our public problems are rooted in the way we use language. Particularly, the lack of material/empirical referent in political talk indicates that they are emotive utterances.

${ }^{3}$ This is not to say that all texts studied by political theorists are in all cases political texts. For example, the confessional and/or biographical genre (e.g. Augustine's Confessions; Rousseau's Emile and Confessions) clearly operates in ways that are very personal and not aimed at producing political outcomes.
} 
the text. Responding to Skinner, John Plamenatz wrenches on this divide to fully separate author from meaning:

Those who say that to understand a theory we must understand the conditions in which it was produced sometimes put their case too strongly. They speak as if, to understand what a man is saying, we must know why he is saying it. But this is not true. We need understand only the sense in which he is using words (1992, xvi).

Here priority is given to the political results that a text was trying to produce, and in that sense it is a viewpoint that privileges the political strands of a text above others. Plamenatz steers us away from looking too closely at the author and instead encourages us to think about the author as an actor trying to publically accomplish a set of goals.

A further implication of this point is that any claim that an author was writing in a less than straightforward manner demands compelling justification. Most pointedly, Strauss's (1952) argument that many political writers employed esotericism as a technique to avoid persecution for unpopular beliefs should be regarded as the exception rather than any sort of rule. Interpretive priority, for Skinner, always lies with the apparent meaning of the text in light of its context, and plausible explanations that contradict that apparent meaning should be viewed with suspicion.

Skinner's work contains two distinct strands, one that focuses on the author as an intentional agent, and another that interprets the author as an actor without trying to get at his intentions. The close criticisms of Skinner's work are many: Nathan Tarcov has criticized him for rejecting timeless truths (in Skinner and Tully, 1988, 195); Keith Graham has argued that texts do not provide their own explanations, so approaching speech as presumed action introduces a set of unsubstantiated premises (Ibid, 155); and by Charles Tully for "bracketing" what he calls "the question of truth" (Ibid, 220). These close critiques all share some basic affinities with Skinner's work, namely a concern for accurate and careful recovery of the historical record and striving to give deference to original authors and past ages in writing history.

\section{Political Science and History}

Political Science studies power and so might seem like a good place to turn for advice in how power functions in historical method, but it struggles to articulate a historical methodology for doing "good" history. In Designing Social Inquiry, King, Keohane, and Verba recognize the validity of history but - unusually - they do not promulgate a necessary methodology. Instead, they leave only two "obvious" signposts as a guide: first, focus on information that addresses your research question and, second, simplify the historical narrative rather than complicating it (King, Keohane, \& Verba, 1994, 54).

Recognizing the inadequate descriptions of qualitative methods given in Designing Social Inquiry, Henry Brady and David Collier gathered together leading qualitative scholars to describe how qualitative work ought to be done. The result, Rethinking Social Inquiry (2004), contains no extended discussion of historical research. The methodist current in political science has done little to provide guidance for those engaged in historical work even though they acknowledge its relevance.

\section{The Reader-Author}

\subsection{Authorship}

Partly as a response to Cambridge School history and partly drawing on literary theory, many scholars have turned away from the original writer and his context as the authority of meaning and instead focused on the reader of a text as a significant source of authority. While this argument has a long history, I will borrow a singular and strong example of this outlook from Don Herzog:

I can put the point polemically. Interpreting the works of John Locke would present just the same challenges if Locke were a robot, if half the volumes were dashed off by his friend Molyneux, or if they all descended from the starry skies. And if Hamlet is ever written by the fabled monkeys hammering away at their typewriters or by a computer spewing out random letters, interpreting it will pose just the same problems as interpreting the Hamlet that Shakespeare wrote (Herzog, 1985, 11-12).

Here Hertzog takes the blunt approach of arguing that an author's identity and context is not an authority for present interpretation of his work. We are left with his work and nothing more. The indeterminacies in the text are not resolved just by the addition of some context. Instead, the reader is forced to fill in at least some of those indeterminacies for himself, to act as his own authority and reading lamp.

Perhaps one well known example that speaks directly to Herzog's assertion about Locke's personal irrelevance will illustrate the loss that comes with a disregard for the author as an actor. Locke's Second Treatise was first 
published anonymously in 1690, and for the next two hundred and sixty-six years scholars basically read it as a justification for the Glorious Revolution of 1688. In 1956, Peter Laslett went back through some of Locke's estate and discovered compelling evidence that the Second Treatise was written in the winter of 1679-80, eight or nine years before conventionally understood. The result of this redating is that the contemporary object of Locke's writing was the Exclusion Crisis rather than the return of William and Mary (Laslett 2005, esp. 43-50). Such a redating changes the Second Treatise form a post hoc justification for limited monarchy to a direct effort to promote parliamentary sovereignty. This single example is one of many that might be given for how the context in which an author writes acts on the interpreter.

Beyond the specific example of Laslett's work, one way context acts on an interpreter is by limiting the range of sensible meanings a text can have for an audience. Gottlob Frege's (1892) insight that the sense of a word is limited by its referent is worth remembering here. If we accept Laslett's argument that the Second Treatise was written prior to 1681, it is nonsensical to say that Locke wrote it as an ex post facto justification of the Glorious Revolution. When the reference of the words changes, so does the range of meaningful senses that those words can convey. It matters whether the Second Treatise was written in 1679 or 1690 or whether Locke or Molyneux was responsible for it if we want to gain anything from it that supersedes the words, sentences, and paragraphs it contains. When we approach classic texts, an engagement with context is necessary if we are to gain an understanding of what the author was up to.

\subsection{The Legal Context}

In The Origins of History, Herbert Butterfield notices that legal history and legal practitioners in England began the push for an autonomous historical method in the seventeenth century. These historians aimed to establish an interpretation of Magna Carta, the English constitution, and affiliated institutions that would bolster the case for representative government during the unrest of their period. Butterfield traces the advancement of historical method to the pushback against this historical construction of the English constitutional tradition, a pushback which after 1660 used documentary evidence to argue that the Magna Carta and affiliated institutions were medieval in character, having little to say to the present day $(1981,192)$. What both sides in this debate agreed upon was that legal events of four hundred years prior were still binding during an era of enlightenment when everything was new and little was impossible. What this attitude should alert us to is that legal history has a unique character that is native to modern history. Any method, then, that purports to be a method of history broadly speaking must also be a method of doing legal history well.

For legal history Skinner's two primary points - (1) that language is action, and (2) that apparent meanings deserve priority over contrived interpretations - are especially important, but they reveal how different legal texts are from political ones. Legal writing works in a different register than political writing. What we now regard as the canon of political philosophy (not unproblematically: see Gunnell, 1978) was written almost entirely by individuals not in a position of authority over their audience. Consequently, it is written in an effort to inform and perhaps persuade people who do not have to obey the writers. Its authors commanded neither armies nor secret police, only pens.

The insight that political texts were written to relative equals has two important implications. First, their outcome was always highly uncertain. When Madison, Hamilton, and Jay wrote the Federalist Papers they certainly hoped that popular opinion would be swayed toward ratifying the American Constitution. Yet, the Federal Farmer and Brutus certainly hoped that just the opposite would happen through their writing. At the time of writing, each new text was thrust into a world of political uncertainty with no necessary or preordained outcome. Political texts are more hope than command because they were presented to an audience whom the author could not compel or command, but only persuade.

The relationship of equality that underlies political reading and writing has a second implication, namely that the author is personally open to retribution for his work, both from governments with authority over him and the citizenry around him. Political texts are not always transparent; they do not always say what they mean directly and plainly. The idea that political texts are sometimes writing esoterically to avoid retribution by those who would be disadvantaged by the institution of their real meaning was most prominently and forcefully advanced by Leo Strauss. In Persecution and the Art of Writing (1952), Strauss argued that free speech is a recent exception to the historical rule of political expression, and that many texts we now regard as canonical were written under the threat of retribution and persecution - stronger than social ostracism - so that the authors were not entirely free to speak their minds. Yet, in Strauss' analysis, this persecution did not stifle dissent, but rather caused the writers to communicate indirectly by "writing between the lines" (Strauss, 1952, 24). Such language would make it past the censor, but would be caught by its intended audience with which the author had a shared 
set of understandings and dispositions toward reading (Ibid, 26). What Strauss taught us about political texts is that under conditions of persecution, texts might have been written to speak at multiple levels to different audiences, and that careful reading could produce an accurate interpretation that was not immediately apparent. ${ }^{4}$

During the 1980's, a group of legal scholars pointed out that law shares much in common with literature, and that legal practitioners and theorists might learn something about interpreting the law by studying how literary scholars study their texts. They focused on how both literary and legal texts are written works read by conscious people (Levinson, 1982), or that both tend to have a storyline that influences their range of possible meanings (Posner, 1988; 2008), or that they can all be read differently without sacrificing honesty or sincerity (Fish, 1980). What they all recognized and were trying to deal with was the reality, demonstrated by research in judicial behavior, that judges read the law differently and that they differ in predictable ways. Judicial behavior collapsed the idea of a separation of powers by making all powers political and power, then, singular. Any separation was a veneer; they were all pursuing political goals. The common knowledge that people genuinely read the same text and take different things away from it in both law and literature explained variance in judicial behavior. While judges differ in their decision-making, that difference does not mean that they are self-consciously behaving as political actors or policymakers. As the techniques of textual analysis "naturally" lead to divergent outcomes, the variance in those outcomes is not necessarily evidence of intention. Law and literature made the point that simply because judges' behavior looks political to a political observer does not mean that the only correct interpretation is a political one or that political goals are an essential characteristic of judging.

Yet, while law and its interpretation have some similarities to literature and literary interpretation, they are not the same activity. Legal writing is different because it is not written from an author to his peers, but rather it is written from a secure position of authority to command an audience defined institutionally as its inferiors. ${ }^{5}$ It is by definition an effort to publically and transparently communicate demands (to pay, to return, to imprison, to release) to another party. In comparison to conventional political texts, legal texts operate overtly, forcefully, and openly. As Robert Cover put it, "Legal interpretation takes place in a field of pain and death [...] a judge articulates her understanding of a text, and as a result, someone loses his freedom, his property, his children, and even his life" $(1986,1601)$. The products and goals of legal interpretation are commands backed up by the real threat of force and violence, and that force and violence make it different from either literature or political texts. While John Locke and Charles Dickens were both great authors of their respected genres, neither had the ability to compel their audience. That difference is important when we approach political and legal texts.

This ability to compel goes beyond the ability of a judge to order actions, conviction, or interpretations in a particular case. In the common law system, those decisions in the past are also binding on the present. ${ }^{6}$ Today when we deal with the common law we deal with statutes, cases, and little else. This disposition - that cases construct the legal world - goes back at least to C.C. Langdell's introduction of the case study method at Harvard Law School in 1871, which based legal education on past judicial decisions (see Langdell [1871] 1999; also Kimbell 2009; Kimbell and Reyes 2005). ${ }^{7}$ While not all legal history is binding in a strict sense, the sort of strict prohibition on anachronism espoused by Skinner is not applicable to legal subjects. In law, the past is an authority commonly recognized by judges, so the past remains very much present.

\subsection{Legal History for the Present}

In his Preface to Philosophy and Government, Richard Tuck lays out "two beliefs about how the history of political thought should be written":

One of them is that to understand the political theories of any period we need to be historians, and we have each been very keen to depict as far a possible the character of the actual life which these theorists were leading, and the specific political questions that engaged their attention. But the other is that a study of the reactions to these questions should not be purely a piece of historical writing. It should also be a contribution to our understanding of how people might cope with broadly similar issues in our own

\footnotetext{
${ }^{4}$ The scope of such methodology, it should be noted, Strauss limits to situations where we have reason to believe that the author faced censorship and the esotericism is a reasonable solution to the problem of being silenced.

${ }^{5}$ Such a construction does not hold in modern appellate courts with multi-judge panels where judges use their writing to try to persuade one another and to descent in an effort to persuade future courts to their viewpoint.

6 This is not the case in the civil law system (see Merryman 2007).

${ }^{7}$ To understand just how important the institution of the case study method was even during his own time, one can look to his obituary in the New York Times. There it is listed as his single professional accomplishment aside from university appointments: "The case system of teaching law, now used in many law schools throughout the country, was inaugurated by him at Harvard." The next line carries the only mention of his personal life when it notes, "Prof. Langdell is survived by a widow" (NYT, July 7, 1906, pg. 7).
} 
time (1993, pg. xi).

What Tuck describes here as a method has two parts, (1) careful history and (2) pointed interpretation for the present. While this might not seem to be a significantly different proposal than those discussed above, it is unique in a small but very important way. While the outlooks discussed above put careful history and present-minded interpretation at loggerheads, Tuck here opens the possibility that they might not be incompatible. In this third section I think through what it might mean to make peace in that tense relationship while doing legal history that naturally brings them together.

In a recent essay on doing legal history, Randall Lesaffer (2008) follows Matthew Carven (2007) in arguing that there are three ways of doing legal history that might be described as history in law, law in history, and history of law. What Lesaffer calls "history in law" is what lawyers do, namely use the legal past to make a case for how things are and should be in the present. Sometimes this is a matter of illuminating how the past justifies a present set of practices, while other times it is a matter of "tamping [past legal practice] firmly down into departed times and places" (Gordon, 1981, 1055). "Law in history," on the other hand, is putting the practice of law into a social context, and examining how law and its environment interact. And finally, "history of law" is a middle road between the other two that tries to explain how law came to be as it is now practiced. Lesaffer argues that there is a "true" form of legal history that uses an unspecified but identifiable set of historical methodologies that "let history speak for itself" (Lesaffer, 2008, 10). He concludes that only those who approach legal history as "law in history" (contextualizing law) or "history of law" (historiography of present legal facts and/or practice) can do "true" legal history. The remainder, using history as evidence for present action, is not historical work and is not the task of the historian.

Proper historical methodology, Lesaffer argues, is a two-step process. First, one must "let the past speak to you in its own voice" by reading primary sources in an attempt to understand what they meant to contemporary readers. Second, when interpreting those texts, the historian should pursue complexity rather than simplicity. It is the job of social science, in Lesaffer's view, to simplify the world and explain it in terms of principles, choices, or laws, but it is history's job to show the past's complexity (Ibid, 16). And, as a final guiding rule he advises that, "one should construct the line of evolution from past to present, and not the other way round." When the line goes from the present to the past it is no longer history, but "genealogy" (Ibid, 17).

Lesaffer's essay on how to do legal history is not an anomaly, but is the most recent in a line of historians who, like Oakeshott, believe that a researcher can have a chaste relationship with his subject and consequently argue that good history is defined by a good faith attempt on the part of the author to get out of his own skin and into his subjects', and not to simplify the past, but rather to truthfully represent its complexity. My objections to this mission statement are many, and I think Lesaffer's methodology is a stark contrast to what Tuck describes as pointed interpretation. Certainly it wishes away the troubles of an author relating to a text in a "truthful" manner, but just as significantly it does not address the problem of starting point or case selection.

We always do research in an effort to create a new and different world, even if the only difference is the addition of knowledge. In that sense, all research is normative. We pursue our preferred norms by studying cases we think are important: if I think poverty is important perhaps I will study the industrial revolution or the contemporary inner city; if I think geography is important perhaps I might study the history of GIS mapping technologies. And, given our outlook on our research subject, we will look differently and see differently. John Gerring summarized this problem in writing that, "What one finds is contingent upon what one looks for, and what one looks for is to some extent contingent upon what one expects to find" $(2004,351)$. One thing Lesaffer's historical method fails to adequately account for is the researcher's starting point, namely the bias that we all begin the process of research from and take with us as we go along.

We all start from somewhere - a place, a time, a context - and it is the linking of our somewhere to a past sometime that makes for a critical sort of history that has purchase on the present and denaturalizes our present practices. Those of us who come after Machiavelli inherit a world that is more or less of our own making. In Chapter 25 of The Prince, Machiavelli tells us that we ought not think of the world as something controlled by nonhuman forces entirely outside of our control. Instead, he tells us that we are in control of about half of our actions, an area of influence that can be expanded through foresight and the use of technology (Machiavelli, 85). Roger Masters writes that, "the novelty of Machiavellian teaching" is, "the use of science and technology to control nature and to achieve, by design, consequences hitherto only achieved by good luck (fortune)" (Masters, 2002, 337; also Masters, 1999). One piece of our mental furniture we inherit from Machiavelli is the basic idea that the world we inhabit is largely of our own making; the human world did not and does not grow out of the ground. It is rather an inorganic compound that came into existence because of its utility to some set of people. 
This understanding of the world is the background to a form of logic that R.G. Collingwood put forward that views our present conditions as a set of solutions to past problems. In contradistinction to conventional propositional logic, Collingwood follows Descartes and Bacon in arguing that truthtelling involves not only answers we receive as facts, but also the questions and efforts that led to those facts/answers (Collingwood, 1939, 30-39). In Collingwood's view, the world as we find it implies a set of past questions and problems, and part of investigating the factual world is to also think through who, how, and why those facts were produced. It should be noted that Collingwood's logic runs from the present to the past, and not from the past to the present as Lesaffer insists that it must. Instead, we are to start admittedly and straightforwardly from a situation and set of facts peculiar, local, and partial to the present so that we can understand the past as a method of coming to self-consciousness as inheritors of what might loosely be called a tradition.

What I have done so far is to set up two ways of doing history. The first, explicated by Lesaffer, looks from the past toward the present to understand what happened. The second, espoused by Collingwood, looks to the past for an explanation of the present. Both of these methods have a place, but the second presents itself as a better methodology for legal history for two reasons. First, the outcome of a search that explicitly begins from a point of present contention will have a greater likelihood of being relevant to the formation and decision of law than one that begins in the past and perhaps never connects with the present. Secondly, when applied to law, it presents a counternarrative to the stories that lawyers usually tell themselves. Robert Gordon writes that conventional legal scholarship has three aims: first, it seeks to rationalize the legal system and its practices; second, it attempts to justify that legal system; and third, it argues that because the system is rational and justified, a set of consequences ought to be pursued. Taken as a whole, this move from rationalization to justification to normative proscription amounts to an apology for the status quo (Gordon, 1981, 1017-1018). Gordon argues that the process of historicizing law challenges this apology by exposing the discontinuities in history to undermine a vision of the present state of affairs as necessary or natural, and also to challenge law's self-concept of being universal and efficacious by illuminating counterexamples to that general outlook in which law acts particularly and/or ineffectively $(1981,1017)$.

In addition to these two tactics critical historians use to disrupt the naturalization of existing social relationships, it is worth recalling Hannah Arendt's comment that law is "a made product" that "contains in itself the violent force contained in all production" $(2005,181)$. Whether we start from Agammben's concept of political exclusion or just the historical fact of Thramasticus' ostracism, law always comes into being and perpetuates itself by its ability to not only create winners and losers, but also to exclude the losers and/or their terms of argument from future discussions. To put it simply, one of law's tasks is to decide between two plausible options and then immediately after that decision behave as if only the chosen option were reasonable. Law thus acts to darken the horizon of possibility by closing the aperture of our reasoning to black out unchosen options and bring into focus only the facts and reasons that presently hold sway in our decision-making. Doing legal history can have a critical function in recovering unchosen options that may prove useful for the present.

The approach I outline above accounts for the multiple sources of legal authority that inform decision-making. To look only to the past with Skinner misses the case and controversy that presses the question now; to turn inward with Herzog denies the institutionalized authority of past practice. On the other hand, tracing the lineage of our present issues back through previous controversies can allow us draw on the multiple sources of authority that command legal decisions today.

\section{References}

Arendt, H. (2005). The promise of politics. New York: Schocken.

Ayer, A.J. (1936). Language, truth, and logic. New York: Dover.

Brady, H. E., \& Collier, D. (Eds.). (2004). Rethinking social inquiry: Diverse tools, shared standards. New York: Rowman and Littlefield.

Butterfield, H. (1931 [1965]). The whig interpretation of history. New York: Norton.

Butterfield, H. (1988 [1981]). The origins of history. London: Eyre Methuen.

Collingwood, R. G. (1978 [1939]). An autobiography. Oxford: Oxford University Press.

Cover, R. (1985). Violence and the word. 95 Yale Law Journal. 1601.

Craven, M. (2007). Introduction: International law and its histories. In M. Craven, M. Fitzmaurice, \& M. Vogiatzi (Eds.), Time, history and international law (pp. 1-25). Boston: Martinus Nijhoff Publishers. http://dx.doi.org/10.1163/ej.9789004154810.i-255.5

Fish, S. (1982). Is there a text in this class? The authority of interpretive communities. Cambridge, MA: Harvard 
University Press.

Frege, G. (1980 [1892]). On sense and reference. In P. Geach, \& M. Black (Eds.), Translations from the Philosophical Writings of Gottlob Frege. New York: Rowman and Littlefield.

Gerring, J. (2004). What Is a Case Study and What Is It Good for? American Political Science Review, 98, 341-354. http://dx.doi.org/10.1017/S0003055404001182

Gordon, R. (1981). Historicism in Legal Scholarship. 90 Yale Law Journal 1017. http://dx.doi.org/10.2307/795938

Gunnell, J. (1978). The myth of the tradition. American Political Science Review, 72, 122-134. http://dx.doi.org/10.2307/1953603

Herzog, D. (1985). Without foundations: Justification in political theory. Ithaca, NY: Cornell University Press.

Ibbetson, D. (2012). Comparative legal history: A methodology. In A. Musson, \& C. Stebbings (Eds.), Making legal history: Approaches and methodologies (pp. 131-145). Cambridge: Cambridge University Press.

Kimball, B. (2010). The inception of modern professional education: C.C. Langdell, 1826-1906. Durham, NC: UNC Press.

Kimball, B., \& Reyes, P. (2005). The "first modern civil procedure course" as taught by C.C. Langdell, 1870-78. The American Journal of Legal History, 47, 257-303. http://dx.doi.org/10.2307/30039514

King, G., Keohane, R., \& Verba, S. (1994). Designing social inquiry. Princeton, NJ: Princeton University Press.

Laslett, P. (2005). Introduction. In J. Locke (Ed.), Two treatises of government. Cambridge: Cambridge University Press.

Lesaffer, R. (2008). Law between past and present, unpublished conference paper. Retrieved from $\mathrm{http}: / /$ papers.ssrn.com/sol3/papers.cfm?abstract_id=1316256

Levinson, S. (1982). Law as literature, 60 Texas Law Review 373.

Masters, R. (1999). Fortune is a river. New York: Penguin.

Masters, R. (2002). Introduction: Niccolo Machiavelli. In S. Cahn (Ed.), Classics of political and moral philosophy. New York: Oxford University Press.

Merryman, J. H. (2007). The civil law tradition: An introduction to the legal systems of Europe and Latin America (3rd ed.). Stanford, CA: Stanford University Press.

Oakeshott, M. (1962). Rationalism in politics and other essays. New York: Basic Books.

Plamenatz, J. (1992). Man and society vol 1: Middle Ages to Locke. New York: Longman Publishing.

Pocock, J. G. A. (1957 [1987]). The ancient constitution and the feudal law: A study of English historical thought in the Seventeenth Century. New York: Cambridge University Press.

Posner, R. (1988). Law and literature. Cambridge, MA: Harvard University Press.

Posner, R. (2008). How judges think. Cambridge, MA: Harvard University Press.

Prest, W. (2012). Lay legal history. In A. Musson, \& C. Stebbings (Eds.), Making Legal History: Approaches and Methodologies (pp. 196-214.). Cambridge: Cambridge University Press.

Skinner, Q. (1969). Meaning and Understanding in the History of Ideas. History and Theory, 8(1), 3-53. http://dx.doi.org/10.2307/2504188

Skinner, Q. (2002). Visions of politics (Vol. 1). New York: Cambridge University Press.

Strauss, L. (1952). Persecution and the art of writing. Glencoe, IL: Free Press.

Tuck, R. (1993). Philosophy and government: 1572-1651. New York: Cambridge University Press. http://dx.doi.org/10.1017/CBO9780511558634

Tully, C., \& Skinner, Q. (Eds.). (1988). Meaning and context: Quentin Skinner and his critics. Princeton, NJ: Princeton University Press.

\section{Copyrights}

Copyright for this article is retained by the author(s), with first publication rights granted to the journal.

This is an open-access article distributed under the terms and conditions of the Creative Commons Attribution license (http://creativecommons.org/licenses/by/3.0/). 